\title{
Immunophenotyping of cerebrospinal fluid cells in virus-associated neurologic diseases
}

\author{
Yoshimi Enose-Akahata', Raya Massoud', Breanna Caruso1, Joan Ohayon', Bridgette Jeanne Billioux', \\ Gloria von Geldern², Bryan Smith², Avindra Nath², Steven Jacobson ${ }^{1 *}$ \\ From 17th International Conference on Human Retroviruses: HTLV and Related Viruses \\ Trois Ilets, Martinique. 18-21 June 2015
}

Various inflammatory neurologic diseases are associated with viral infections. These agents may cause direct damage of infected cells associated with immunological alterations such as chronic activation, immunodeficiency and infiltration of inflammatory cells into the central nervous system that underlie the pathogenesis of inflammatory neurologic diseases. Therefore, characterization of local immune responses that are associated with the inflammatory milieu may provide evidence or pathogenic "signature" of an immunopathogenic process in virus-associated neurologic diseases. Multicolor flow cytometry is a powerful technology to provide a large amount of cellular information for each sample and allow identification and characterization of novel cell subsets, even rare cell population. Using the technique, we characterized the cellular immunophenotypes (CD4+ and CD8+ T cells, B cells, monocytes and NK cells) in cerebrospinal fluid (CSF) and blood of patients with virus-associated neurologic diseases including HTLV-1 associated myelopathy/tropical spastic paraparesis (HAM/TSP; $\mathrm{n}=18$ ), HIV adequately treated with antiretroviral drugs $(n=28)$, multiple sclerosis $(M S ; n=7)$ and progressive multifocal leukoencephalopathy (PML; $\mathrm{n}=8$ ) compared to healthy volunteers $(\mathrm{n}=8)$. $\mathrm{CD} 4+$ and $\mathrm{CD} 8+$ $\mathrm{T}$ cells were significantly altered among the groups, and the CD4/CD8 ratio reduced in HIV, HAM/TSP and a subset of PML, but elevated in MS. In patients with $\mathrm{HAM} / \mathrm{TSP}$, activated CD4+ T cells were significantly increased in the CSF as well as the blood and correlated with HTLV-1 proviral DNA loads. HAM/TSP patients had an increased frequency of effector CD4+ and CD8+

\footnotetext{
* Correspondence: jacobsons@ninds.nih.gov

'Viral Immunology Section, Neuroimmunology Branch, National Institute of Neurological Disorders and Stroke, National Institutes of Health, Bethesda, MD, USA

Full list of author information is available at the end of the article
}

$\mathrm{T}$ cells in the blood, but not in the CSF. Antibody secreting B cells were elevated in the CSF of patients with HAM/TSP, MS and PML and were significantly correlated with intrathecal HTLV-1 Gag-specific antibody responses in HAM/TSP patients. Immunophenotyping of CSF cells may reflect immune pathology in inflammatory neurologic diseases and can serve to highlight differential diagnoses that may lead to a better understanding of disease pathogenesis and clinical treatment.

\section{Authors' details}

${ }^{1}$ Viral Immunology Section, Neuroimmunology Branch, National Institute of Neurological Disorders and Stroke, National Institutes of Health, Bethesda, MD, USA. ${ }^{2}$ Section of Infections of the Nervous System, National Institute of Neurological Disorders and Stroke, National Institutes of Health, Bethesda, MD, USA.

Published: 28 August 2015

doi:10.1186/1742-4690-12-S1-P86

Cite this article as: Enose-Akahata et al.: Immunophenotyping of cerebrospinal fluid cells in virus-associated neurologic diseases. Retrovirology 2015 12(Suppl 1):P86.

Submit your next manuscript to BioMed Central and take full advantage of:

- Convenient online submission

- Thorough peer review

- No space constraints or color figure charges

- Immediate publication on acceptance

- Inclusion in PubMed, CAS, Scopus and Google Scholar

- Research which is freely available for redistribution 